\title{
Cystic Echinicoccosis of Cattle of Sheep in Ordu
}

\author{
Ülkü Karaman ${ }^{1}$, Özgür Enginyurt ${ }^{2}$, Pınar Naile Gürgör ${ }^{3}$ \\ ${ }^{1}$ Department of Medical Parasitology, Faculty of Medicine, Ordu University, 52200, Ordu, Turkey \\ ${ }^{2}$ Department of Family Medicine, Faculty of Medicine, Ordu University, 52200, Ordu, Turkey \\ ${ }^{3}$ Department of Histology and Embryology, Faculty of Medicine, Ordu University, 52200, Ordu, Turkey
}

Received: 16 August 2015 accepted: 22 August 2015/ published online: 30 August 2015

(C) Ordu University Institute of Health Science, Turkey, 2015

\begin{abstract}
Objective: Cystic Echinococcosis (CE) a parasitic disease that affects both human and animal health, shows a broad distribution as well. Parasites are frequently seen in humans and animals living in less developed countries. It is difficult to diagnose in intermediate hosts since the clinical findings are not evident enough. Early diagnosis increases the success rate in the treatment of the disease. The risk factors of the $\mathrm{CE}$ in humans can be listed as working in a rural area, keeping a dog, lack of information about the disease, age, gender and potable water supply. Surgical and chemotherapeutic treatment costs of the CE patients, their hospital expenses, deaths, loss of income caused by the fact that they are not able to work when they are ill and during the recovery period create a heavy burden on the economies of the countries. When economic and social losses regarding the cases which cannot be treated since they are not diagnosed are taken into account, control of the disease becomes highly significant. Furthermore, loss of carcass value in sheep, goats and cattle, loss of infected livers and implicit losses in yield cause serious economic loss. Methods: According to the data obtained, no study has been conducted in Ordu province concerning the epidemiology of Hydatid cyst. The aim of this study is to make a retrospective evaluation on the data of Cystic echinococcosis found in sheep and cattle slaughtered between the years 2008-2014 in the abattoir affiliated to the Municipality of Ordu, a province which also has some stray dog population.

Results: The data for this study have been obtained from the abattoir records. In the abattoir affiliated to the Municipality of Ordu 26117 cattle and 1791 sheep were slaughtered between 2008-2014. As a result of the analysis performed, 1149 cattle and 114 sheep were infected with cystic echinococcosis.

Conclusion: Presence of cattle and sheep with hydatid cyst in this study supports the idea that there are infected dogs in this region. This situation can be explained by the fact that the parasite can complete its evolution through the animals slaughtered in an uncontrolled manner. The study has also shown us that the control activities should be conducted in accordance with the epidemiology of the parasite and the results obtained.
\end{abstract}

Key words: Cystic echinococcosis, Echinococcus granulosus, Ordu

Address for Correspondence/reprints:

Ülkü Karaman

E-mail address: ulkukaraman44@hotmail.com

*This article was presented at the $7^{\text {th }}$ Hydatidology Congress, Ordu, 2014.

DOI: $10.19127 / \mathrm{mbsjohs.56265}$

\section{Introduction}

Hydatid cyst is a zoonosis found in intermediate hosts and caused by the metacestode form of the tapeworm Echinococcus granulosus. The adult form of the parasite resides in small intestines of the carnivore such as dogs and foxes; and the larval form resides in internal organs of the humans and animals such as sheep, goats, cattle and pigs which are intermediate hosts. The disease can localise mainly in the liver and lungs and almost in all other 
organs such as kidneys, spleen, brain, bones and heart. Animal movements and its capability of adapting to various types of hosts, the host, environmental and social factors are influential in the spread of Echinococcus granulosus. The larva of the parasite called the hydatid cyst mostly grows in internal organs, livers and lungs of the farm animals. The cysts containing protoscolex are called fertile cysts. Older sheep have a higher number of fertile cysts. Adult tapeworms grow from the protoscolex released in the small intestines of the dogs eating offal containing fertile cysts. In the cities which have less stray dogs, the dogs generally cannot reach to internal organs of the sheep (Oku et al., 2004). However, in rural areas, the dogs become infected by eating lungs and livers of the older sheep slaughtered. Humans become infected when they receive the eggs of the tapeworm from contaminated environment or by close contact with infected dogs. Therefore, CE is mostly found in people who live in unproductive rural areas with sheep and dogs kept for protecting and herding these animals (Oku et al., 2004; Craig et al., 2007). Surgical and chemotherapeutic treatment costs of the CE patients, their hospital expenses, deaths, loss of income caused by the fact that they are not able to work when they are ill and during the recovery period create a heavy burden on the economies of the countries. When economic and social losses in the cases which cannot be treated since they are not diagnosed are taken into account, control of the disease becomes highly significant. Furthermore, loss of carcass value in sheep, goats and cattle, loss of infected livers and implicit loss in yield lead to serious economic loss (Perry and Randolph, 1999; Torgerson, 2003; Budke et al., 2005; Sarı̈zkan and Yalçın, 2009). E. granulosus can be seen in almost all continents in the world. The incidence rate of the parasite has been identified higher in some regions of South America, Australia, Africa and Eurasia. There are also some regions where the infection is defined as endemic or sporadic. Furthermore, it has been reported that the parasite has never been found in Greenland and Iceland (Akyol, 2004; Kilimcioğlu and Ok, 2004).

This disease, which closely concern human and animal health in Turkey, is seen in Eastern, North Eastern and Central Anatolia and rarely in the western region where the people, who migrated from our eastern region. According to the studies carried out with regard to the epidemiology of the parasite, in the neighbouring countries of Turkey, the incidence rate is 0.7 $20 / 100000$ in humans, $5.8-82 \%$ in cattle, $30.6-80 \%$ in sheep, $24 \%$ in goats and 5-8.4\% in pigs (İnan et al., 2001; Kachani et al., 2001; Kurdovar et al., 2001; Saeed, 2001; Soturaki et al., 2001). In Turkey it is reported that the incidence rate is approximately $0.87-6 / 100000$ in humans, $25.9 \%$ in cattle, $30.6 \%$ in sheep, $12.7 \%$ in goats and $1.4 \%$ in horses (Özçelik, 2001; Gıcık et al., 2004).

According to the data obtained, no study has been conducted in Ordu province concerning the epidemiology of Hydatid cyst. The aim of the study is to make a retrospective evaluation on the data of Cystic echinococcosis found in sheep and cattle slaughtered between the years 2008-2014 in the abattoir affiliated to the Municipality of Ordu, a province which also has some stray dog population.

\section{Materials and Methods}

This study is made a retrospective evaluation on the data of Cystic echinococcosis found in sheep and cattle slaughtered between the years in January 2008-July 2014 in the abattoir affiliated to the Municipality of Ordu, a province. Age of the animals' determination could not be made due to the cutting of retrospective assessment.

\section{Results}

The study revealed that 26117 cattle and 1791 sheep were slaughtered from 2008 to 2014 .

The animals were brought for slaughter to Ordu Municipality Abattoir mainly from Samsun, Amasya, Tokat, Sivas and Giresun; and rarely from Adana, Kars and Ağrı provinces. As a results of the evaluation performed $4.4 \%$ (1149/26117) cattle and $6.36 \%(114 / 1791)$ of the sheep were found to be positive.

No study was conducted in order to find out if the cysts were fertile or not.

The slaughter rates of the cattle and sheep by years are given in the table.

\section{Discussion}

Cystic echinococcosis, which develops as a result of the infestation of Echinococcus granulosus larva that are connected to the tapeworm family, 
is a parasitic zoonosis threatening human and animal health in the world as well as in Turkey. While this infection frequently seen particularly in rural area

Table: Distribution of the slaughtered cattle and sheep by years

\begin{tabular}{ccc}
\hline \multirow{2}{*}{ Year } & The number of slaughtered animals \\
\cline { 2 - 3 } & Cattle & Sheep \\
\hline 2008 & 6051 & 566 \\
2009 & 5098 & 469 \\
2010 & 2520 & 233 \\
2011 & 2004 & 76 \\
2012 & 4233 & 188 \\
2013 & 4125 & 108 \\
2014 & 2086 & 151 \\
\hline Total & 26117 & 1791 \\
\hline
\end{tabular}

populations causes a disease prognosis that can be quite serious and sometimes lethal in humans, it also causes economic loss because of the structural and functional disorders developing in various organs and tissues of the animals (Balkaya and Şimşek, 2010).

Turkey is among the countries where this disease is endemic. According to the studies conducted throughout Turkey, it is reported that $E$. granulosus is seen with a rate of $0.94-54.5 \%$ (Zeybek and Tokay, 1990; Ayçiçek, 1998) in dogs and the rate for cystic echinococcosis is $4.5-56.5 \%$ in cattle (Erkut and Kahyaoğlu, 1996; Poyraz et al., 1990; Avc1oğlu et al., 2010). In this study, hydatid cyst is found in $4.39 \%$ of the cattle and in $6.36 \%$ of the sheep slaughtered in the abattoir affiliated to the Municipality of Ordu.

In a retrospective study conducted in Hatay province between the years 2003-2007 with the aim to identify the prevalence of hydatid cyst, 1.158 (\%3.23) cystic echinococcosis cases defined in 35.812 cattle slaughtered in the abattoir affiliated to the Municipality of Antakya were analyzed. In the light of the information gathered, it is reported that the prevalence was $5.448(\% 5.8)$ in $2003,8.800(\% 2.7)$ in $2004,9.539(\% 2.6)$ in $2005,7.875(\% 2.6)$ in 2006, and $3.850(\% 3.2)$ in 2007 (Hakverdi et al., 2008).
In a study aiming at defining the seasonal prevalence of cystic echinococcosis, 203 (5.3\%) out of 3846 cattle slaughtered in the abattoir of Kars Municipality throughout one year had cystic echinococcosis. According to this study, it was observed that the infection had the highest prevalence in spring (37.4\%) and it was less frequently seen in autumn (15.8\%) (Demir and Mor, 2011).

Balkaya and Şimşek (2010) investigated 2088 cattle slaughtered at the Combined Facility of Erzurum Meat and Fish Authority and in a private abattoir in order to define the epidemiology of fascioliasis and hydatidosis in Erzurum. All the internal organs, liver and lungs in particular, of the slaughtered animals were analyzed and hydatid cysts were found in 717 (34.3\%) cattle. Hydatid cysts were observed only in the lungs in 520 animals $(72.5 \%)$, only in the liver in 83 animals (11.6\%), both in the lungs and in the liver in 109 animals (15.2\%), in the spleen in 4 animals $(0.6 \%)$ and in the heart in 1 animal $(0.1 \%)$.

In another study conducted in Sivas, on the other hand, 765 cattle slaughtered in three different abattoirs in April and May were investigated and $273(35.7 \%)$ were defined positive. $66(8.6 \%)$ of the animals, which were positive, had hydatid cysts only in the liver and 103 had only in the lungs (Acıöz et al., 2008). When the rarely localised hydatid cyst cases which are reported in humans and animals are examined according to the data obtained from the studies carried out on humans and animals, it seems as if the number of cases were higher in humans. This situation can be attributed to the factors such as the diagnosis opportunities being more limited for animals compared to humans and not being able to perform a detailed examination after slaughter (Avcioğlu et al., 2010).

\section{Conclusion}

No study has been conducted in this region before concerning the epidemiology of the parasite. It is thought that this study can be a reference for future epidemiological studies. The presence of cattle and sheep with hydatid cysts according to the study supports the idea that there are infected dogs in this region. This situation can be explained by the fact that the parasite can complete its evolution through the animals slaughtered in an uncontrolled. 
Acknowledgements: Thank slaughterhouse employees and the veterinarian.

Peer-review: Externally peer-reviewed.

Author Contributions: Concept UK; Design UK, ÖE; Supervision PNG; Data Collection and/or Processing UK, ÖE, PNG; Analysis and/or Interpretation UK, PNG Literature Review UK, ÖE; Writing UK; Critical Review UK, ÖE, PNG

Conflict of Interest: No conflict of interest was declared by the authors.

Financial Disclosure: The authors declared that this study hasn't received no financial support.

\section{References}

Acıöz M, Celiksöz A, Ozçelik S, Degerli S. Comparison of the results of examination of fecal samples from students at six months intervals in the alahaci village primary school in Sivas. Turk Parazitol Derg's, 2008; 32(3): 205207.

Akyol ÇV. Epidemiology of Echinococ Type. Altıntaş N, Tınar R, Çoker A, editors. Echinococcosis. İzmir: Hidatidoloji Association; 2004.p.259-83.

Avcıoğlu H, Terim Kapakin KA, Balkaya İ. Cases of rare located of Cystic Echinococcosis in cattles. Kafkas Üniv Vet Fak Derg, 2010; 16(1): 139-141.

Aycicek H, Sarnmehmetoglu HO, Tanyuksel M. Ankara in stray dogs distributions intestinal helminths seen and their importance in terms of public health. Turk Parazitol Derg's, 1998; 22, 156-158.

Balkaya, İ, Şimşek, S. Prevalence and economic importance of hydatidosis and fasciolosis in slaughtered cattle in Erzurum province of Turkey. Kafkas Üniv Vet Fak Derg, 2010; 16(5): 793-797.

Craig PS, McManus DP, Lightowlers MW, et al. (2007). Prevention and control of cystic echinococcosis. Lancet Infect Dis, 7, 385-394.

Demir P, Mor N. Seasonal Distribution and Economic importance of Cystic Echinococcosis in cattle slaughtered at Kars municipal abattoir, Turk Parazitol Derg's, 2011; 35: 185-188.
Erkut HM, Kahyaoğlu T. Fasciola gigantica situation in our region and made helminthologically research and in Izmir and Buca and Bornova slaughterhouse. Bornova Vet Araş Enst Derg, 1996; 13, 19-23.

Gıcık Y, Arslan MÖ, Kara M, Köse M. Prevalance of cystic echinoccosis in cattles and sheeps slaughtered at Kars province. Turk Parazitol Derg's, 2004; 28(3): 136-139

Hakverdi S, Çulha G, Canda Ş, Yaldız M, Altıntaş S. Problem of Cystic Echinococcoss in Hatay. Turk Parazitol Derg's, 2008; 32(4): 340-342.

İnan M, Dağlı O, Soyuöz Ş, Zorlu D, Akalın A, Eralp S, Altınoğlu T. The epidemiodlogy of hydatidosis in Turkish Republic of Northern Cyprus. XXth International Congress of Hydatidology, 2001; P62, June, 4-8, Kuşadas1Turkey.

Kachani M, Ouhelli H, Lyagoubi M, Berrada M, Macpherson C, Andersen F. Hydatid disease in the Maghreb. XXth International Congress of Hydatidology, 2001; RT9, 74, June, 4-8, Kuşadas1-Turkey.

Kilimcioglu A, Ok UZ. Human, epidemiology of echinococcus species, geographic prevalence and condition of Turkey. Izmir. Altıntaş N, Tinar R, Çoker A, editors. Echinococcosis. İzmir: Hidatidoloji Derneği; 2004.p.129-40.

Kurdovar R, Jordanova D, Halatcheva M. Current status of hydatidosis in Bulgaria (1991-2000). XXth International Congress of Hydatidology, 2001; RT9, 70, June, 4-8, Kuşadas1-Turkey.

Martinez-Perez D, Varela-Morales $M$. Conservative treatment of dentigerous cysts in children: a report of 4 cases. J Oral Maxillofac Surg 2001;59(3):331-3.

Oku Y, Malgor R, Benavidez U, Carmona C, Kamiya H (2004). Control program against hydatidosis and the decreased prevalence in Uruguay. Int Congr Ser, 1267, 98-104.

Özçelik S. Cystic echinococcosis and echinococcosis in Turkey. XXth International Congress of Hydatidology, 2001; RT9, 69, June, 4-8, Kuşadas1-Turkey.

Poyraz O, Özçelik S, Saygın G, Genç S. Hydatid disease incidence slaughtered Sheep and cattles The Meat and Fish of Institution of Sivas in Combine. T Parazitol Derg, 1990; 14, 35-40. 
Saeed İ. Epidemiology of chinococcosis in Iraq and other Middle East Countries: An overview. XXth International Congress of Hydatidology, 2001; RT9, 73, June, 4-8, Kuşadas1-Turkey.

Soturaki S, Papadopoulos E, Himonas C, Korkoliakou P. Hydatidosis-Echinococcosis in Greece. XXth International Congress of Hydatidology, 2001; RT9, 71, June, 4-8, Kuşadas1-Turkey.

Zeybek H, Tokay A. Distribution of Echinococcus species in domestic and wild Canidae in the region Ankara, to investigate the incidence of the cyst form and control possibilities. Etlik Vet Mikrobiyol Derg, 1990; 6, 1-19 